\title{
ORIGINS OF MEDICAL EDUCATION ON THE TERRITORY OF MODERN UKRAINE
}

\author{
${ }^{\mathrm{a}}$ ALLA KULICHENKO, ${ }^{\mathrm{b}}$ MARYNA BOICHENKO \\ ${ }^{a}$ Zaporizhzhia State Medical University, 26 Maiakovskoho Av., \\ Zaporizhzhia, Ukraine 69035. \\ ${ }^{b}$ Sumy State Pedagogical University named after \\ A. S. Makarenko, 87 Romenska Str., Sumy, Ukraine 40002. \\ email: ${ }^{a}$ alla.kulichenko@gmail.com, ${ }^{b}$ marinaver18@gmail.com
}

Abstract: The article deals with the origins of Ukrainian medical education during two historical periods - the period of Proto-Slavic medicine $\left(6^{\text {th }}\right.$ century BC $-7^{\text {th }}$ century $\mathrm{AD})$ and the period of folk, secular and monastic medicine of the Kyivan Rus $\left(9^{\text {th }}-\right.$ $13^{\text {th }}$ centuries AD). There are the following methods, applied in the research: content analysis and generalization of references, method of historical reconstruction, and cultural and historical method. The period of Proto-Slavic medicine is characterized as cultural and historical method. The period of Proto-Slavic medicine is characterized as the beginning of the activity of healers, fortune-tellers, priests, magicians, midwives, who combined the rational things with the irrational ones. In the period of folk, secular, and monastic medicine of the Kyivan Rus there was a combination of pagan
and Byzantine ideas in all spheres of life.

Keywords: development, folk medicine, medical education, monastic medicine, ProtoSlavic medicine, secular medicine, Ukraine.

\section{Introduction}

Medicine and medical education are always linked to one another, because all medical manipulations, treatment processes need to be contemplated, and therefore memorized, learned, experimented, concluded, etc. So, there is a classic combination of theory and practice.

Besides, in this article, we will consider that education is the transfer of accumulated values and knowledge of any society, where the environment and all activities are elements of the educational process and the representatives of the older generation are teachers (Education, 2020).

It is worth mentioning that the history of modern Ukraine dates back to ancient times with many cultures and many peoples interwoven at different stages. Thus, we will describe medicine and, accordingly, medical education in the Proto-Slavic period $\left(6^{\text {th }}\right.$ century BC $-7^{\text {th }}$ century AD) and at the age of the Kyivan Rus $\left(9^{\text {th }}-13^{\text {th }}\right.$ centuries AD), using the given principle.

\section{Methods}

There are the following methods in the research: (i) content analysis and generalization of historical, literary, and pedagogical sources - to present a holistic picture of the origins of Ukrainian medical education during the period of Proto-Slavic medicine $\left(6^{\text {th }}\right.$ century BC $-7^{\text {th }}$ century AD) and the period of folk, secular and monastic medicine of the Kyivan Rus $\left(9^{\text {th }}-13^{\text {th }}\right.$ centuries AD); (ii) method of historical reconstruction - to create a periodization of the origins of Ukrainian medical education and to reconstruct logically historical events; (iii) cultural and historical method - to clarify the specific features of the development of medicine and medical education in the mentioned chronological periods.

\section{Results and discussion}

3.1 Origins of Ukrainian medical education. Proto-Slavic medicine $\left(6^{\text {th }}\right.$ century $\mathrm{BC}-7^{\text {th }}$ century $\left.\mathrm{AD}\right)$

During the Chalcolithic Age, in the $6^{\text {th }}-4^{\text {th }}$ centuries BC, the Proto-Slavic society, which lived in the eastern half of the great Slavic homeland, reached a higher stage of development (Mirskii \& Bogoiavlenskii, 2018). At that time, the Trypillia tribes and Scythians lived in the territory of modern Ukraine, whose medical practice was crucial among all other nations.

The Trypillia tribes settled from the Carpathians to the left bank of the middle Dnipro and from Volhynia to the lower reaches of the Danube and the northern coast of the Black Sea. Trypillia tribes paid special attention to the sick treatment, and children care. Ye. Palamarchuk and I. Andrievskyi point out that "the centuries-old experience of Trypillia medicine made it possible to correlate changes in the body with external changes and to make whole "portraits" of diseases. Trypillians, like our contemporaries, suffered mainly from the stomach, kidneys, heart diseases as well as from cold and so on. The people from Trypillia tribes also knew about the surgery" (Palamarchuk \& Andriievskyi, 2005).

As the Trypillians were intensively engaged in agriculture and cattle breeding, they used plants and animal parts during the treatment of the sick. Shamans, magicians, and healers made infusions, decoctions, ointments, protective amulets, and medallions. They also appealed to the spirits of their ancestors with the help of certain rituals and words, because for Trypillians magic made it possible to put religion into practice. Besides, only selected representatives of the Trypillia tribes had medical knowledge. Sometimes the medicine of the Trypillians and Scythians was intertwined.

The Scythians established Scythia, "a Proto-Slavic state located in the area from the Caspian Sea along the northern Black Sea coast to the Carpathians. Witnesses of the greatness of Scythia are numerous mounds throughout Ukraine - the burial places of leaders" (Blikhar, 2004), as well as Greek chroniclers, who have retained information about the life and work of the Scythians. Scythia became a large state in the northern Black Sea region, which was the sphere of interests of the Mediterranean world (Blikhar, 2004).

The arsenal of medicines was considerable in Scythia. The Scythians used mostly herbal drugs. Scythian healers distinguished poisonous plants from harmless ones that they used for food. Scythian midwives helped mothers with children and accumulated knowledge and skills from generation to generation. Also, Scythian healers were familiar with enema accessories, massage, cold and hot treatments (Blikhar, 2004), for example, the so-called "Scythian baths". The Scythians used hemp seeds and, covered with clothes, threw them on hot stones; at once it formed a stream, and the Scythians were shouting in delight, and the stream was instead of a water bath (The History, 2020). Besides, the Scythians used unique methods of mummification, when the royals died.

Magicians, sorcerers, and sacrificers treated the Scythians. However, they applied an irrational rather than a rational principle, in many cases, their treatments were unsuccessful, and patients died in agony. Herodotus wrote that "Scythia has many magicians who predict the future with the help of willow sticks. A large bundle of these sticks is brought and placed on the ground. The magician unties the bundle and puts each stick while uttering his prophecy: then, while he is still speaking, he gathers the sticks and puts them back in the bundle" (The History, 2020). In most cases, this ritual predicted the consequences of the disease - either recovery or death.

In the treatise "Air, Waters, and Places", authored by the father of medicine Hippocrates, there is a mention of the Scythians as stable, strong and cruel people, and a description of various medical painful manipulations during illness - "horseback riding, during which the legs are constantly hanging on the sides of the horse, causes tumours; then during the strong development of this disease, there is a sprain of the thighs and lameness. The Scythians treat them as follows: at the first signs of the disease they cut on both sides of the veins behind the ears; when the bleeding stops, patients with weakness fall asleep; then some patients wake up healthy, others do not. It seems that this method of treatment has a detrimental effect on the seminal fluid: there are veins near the ears, as a result of which the persons who have had this operation become incapable of fertilization...” (Hippocrates, 1947).

As for the existence of medical schools, M. Mirskyi and $\mathrm{N}$. Bohoiavlenskyi joined to the statement of M. Dumka that in 
the mixed Greco-Scythian settlements and some regions of Scythia, young people liked medicine and were even engaged in medical circles. Moreover, Scythian healers and magicians taught not only their relatives but also strangers for a fee (Mirskii \& Bogoiavlenskii, 2018).

After the Scythians, the Sarmatians, Goths, and Huns lived in the territory of modern Ukraine. Healers or magicians continued to provide medical care, using herbal medicine, and turning to their deities.

S. Skolozdra and B. Tchaikovskyi emphasize that "the arrival of Slavs during the $6^{\text {th }}-7^{\text {th }}$ centuries AD appears so sudden and ubiquitous that in historical literature it is sometimes called the silent Slavic revolution. <...> However, it should be considered that a single people called "Slavs" never existed, and the collective term "Slavs" is now used to denote a set of tribes, each of which had its origin and history” (Skolozdra \& Tchaikovskyi, 2011).

In the $6^{\text {th }}$ century, in the middle of the Dnipro, Slavic tribes formed a powerful union. It included Poliany, Drevliany, Kryvychi, Radimychi, Severiany, and others. These peoples united around Kyiv and became known as Ros or Rus (Mirskii \& Bogoiavlenskii, 2018).

The Slavs worshipped the gods, and therefore the healing and transmission of medical knowledge were also associated with pagan rituals and beliefs. Thus, the famous Ukrainian folklorist M. Kostomarov noted that "the Slavs thought that the deity Alive (Zhyvyi) had turned into a cuckoo to announce the time of year and longevity to people. Therefore, sacrifices were especially offered to him; when people first heard the cuckoo forging in the spring, they asked how many years to live, and determined the number of future years by how many times the bird forged after the question” (Kostomarov, 1994).

The Slavs appealed to magicians, fortune-tellers, healers, and sorcerers. Since medicine was magic for them, the knowledge of herbs was a miracle. The people naively believed that the power inherent in herbs was as healing as the power of whispering, and inspiring, with the help of which one could heal a person and send disease on him, protect him from danger, and even kill him. Usually, the patient went to the healer for medication against the disease. He did not ask about a higher being or power that, through the healer, gave power to medicine. In this case, there was faith in the power of the thing itself (Kostomarov, 1994).

Besides, the Slavic tribes respected plants, animals, and flowers, which were not only medicinal ones. They also symbolized specific states of health. For example, according to the beliefs of the Slavs, maple had a mysterious healing power. M. Kostomarov stated that "the Kupala Night was of great importance for the Slavs. On this holiday, the Slavs were collecting herbs, both medicinal and those to which the imagination gave healing power. They also considered water, fire, and wreaths from the Kupala holiday to be healthy. On that Night they could find some charcoal under the mugwort, which cured diseases” (Kostomarov, 1994).

So, the Slavic tribes that lived around Kyiv and throughout modern Ukraine had laid the foundations for "folk medicine".

3.2 Origins of Ukrainian medical education. Folk, secular and monastic medicine of the Kyivan Rus $\left(9^{\text {th }}-13^{\text {th }}\right.$ centuries AD).

Ancient Rus stretched from the Baltic Sea to the Black Sea and from the Western Bug to the Volga. In the Middle Ages, it became one of the important states, which was founded in the $9^{\text {th }}$ century instead of small principalities. The Kyivan Rus quickly became a powerful territory with a unique culture and medicine (Mirskii \& Bogoiavlenskii, 2018).

From the beginning of its establishment, the Kyivan Rus was pagan with the beliefs and ideas of the Slavic tribes. L. Zmieiev argued that "neither Olha, who went to Constantinople, nor the Greek Princess Anna, Volodymyr's fiancée, nor later Metropolitan Yefrem, the eunuch from Mount Athos, brought with them or called Greek doctors" (Zmeev, 1896). Since the inhabitants of the Kyivan Rus, firstly, did not like to be treated. Secondly, they had a sufficient number of pagan doctors (magicians, healers, midwives, etc.). Thirdly, people often sought help from surgeons during the war and with domestic injuries (Zmeev, 1896).

Pagan doctors transferred knowledge to pupils at home, where they were treating patients. According to L. Zmieiev, "the method of teaching medicine was usually ancient and practical. $<\ldots>$ There was a hereditary transfer of theoretical and practical knowledge from teacher to assistant, pupil, as well as the right for free independent practice after a certain exam before the teacher. The first place was for surgical knowledge, and women and children were at the last one" (Zmeev, 1896).

O. Viesielkova notes that "folk medicine used knowledge passed down from generation to generation. Thus, there were family medical schools, which existed until the $17^{\text {th }}-18^{\text {th }}$ centuries. However, there was no clear training program for future doctors, and the acquired medical knowledge and experience had a spontaneous and empirical meaning” (Veselkova, 2018). Folk medicine showed folk ideas about human anatomy and physiology, folk understanding of the origin of diseases, methods of diagnosis and prevention, sanitation, classification of drugs, a combination of rational and irrational principles (Ivashchenko, 2012)

One of such doctors was Ivan Smera, a Cuman (Polovtsian), who served Volodymyr the Great. He was probably the son of a man close to the prince, mastered the craft of medicine abroad, first studying it in the Kyivan Rus (Zmeev, 1896). Thus, Ivan Smera was one of the first secular doctors.

However, M. Mirskyi and N. Bohoiavlenskyi believe that "Smera could be a magician (healer, folk doctor), i.e. a representative of folk medicine, and, of course, a great specialist, otherwise he would not have become a doctor of Volodymyr the Great. Also, he was a pagan and accepted Christianity only during a trip to Egypt. Therefore, this study of medicine (for example, in Byzantium) and acquaintance with the achievements of ancient medicine were hardly available to him before. He did not work in monastic hospitals because they did not exist then" (Mirskii \& Bogoiavlenskii, 2018).

L. Zmieiev provided us with information concerning the absence of hospitals in the pre-Christian Kyivan Rus. He wrote that "medical establishments, during the time of Volodymyr the Great, could not appear quickly. Although the existence, for example, according to the Norwegian saga, of Princess Olha's hospital cannot be ruled out” (Zmeev, 1896).

After the official baptism of the Kyivan Rus by Volodymyr the Great in 988, Christian churches and monasteries began to be actively built. Thus, in 1051, the Pechersk Monastery (now known as the Kyiv Pechersk Lavra), one of the first Christian monasteries of the then Kyivan Rus and one of the oldest historical and cultural monuments of modern Ukraine, was founded by Antonii Pecherskyi (983 - 1073). I. Zhylenko argues that "the establishment of such a monastery was not just a natural result of the Baptism of Ukraine, it was necessary for its further spiritual progress" (Zhylenko, 2001).

According to historical records, the doctor and founder of the Pechersk Monastery, Anthonii decided to "choose a place in three layers (approximately 3200 m. - A. K., M. B.) from Kyiv down the Dnipro, on its high bank and settled in a cave dug for secret exploits and prayers by Illarion, the priest of the Berestiv village” (Kiyevo-Pecherskaya..,1909, Kolpakova, 2001). In 1055 - 1056 Feodosii (1008 or 1036 - 1074), later abbot of the Pechersk Monastery (Kiyevo-Pecherskaya.., 1909), joined Anthonii. 
In the $11^{\text {th }}$ century, the Pechersk monastery was the birthplace of monastic medicine. In the $11^{\text {th }}$ century also there were the first "monastic hospitals. The Nikon Chronicle proved that in 1091 Metropolitan Yefrem built a hospital in Pereiaslav" (Marchukova, 2003). A feature of monastic medicine was the combination of experience of folk healers and medical knowledge from the Byzantine state. Thus, most monks who provided medical care in the monasteries were from family medical schools (Veselkova, 2018).

With the first monastic hospitals, everyone could visit the monks-doctors (healers): from wealthy to ordinary people. Because in the new "Christian culture" there was the idea that God punished the sinner with diseases or sent trials to the righteous, reminding both of them of the transiency of human life" (Marchukova, 2003). So the only way out was to turn to prayers and monks who could help people. Mentions of treatment in the Pechersk monastery are recorded in the Kyivan Cave Patericon ( $13^{\text {th }}$ century), a collection of stories about the establishment of the Pechersk monastery and the life of the first monks in it. M. Dzeman states that "regarding the development of medical knowledge, it should be noted that the monastic medicine of the Kyivan Rus followed the tradition of the healing process in a threefold combination - soul, spirit, and body" (Dzeman, 2018).

Thus, the founder of the monastery, Anthonii "healed the sick with his food, and they believed that they were given a medicinal spell, but were healed by his prayers" (Kolpakova, 2001). Anthonii had a pupil whose name was Ahapit (? - 1095). The Kyivan Cave Patericon states that "if whoever was sick from the fraternity, he left his cell and came to his sick brother and served him, lifting and helping him, carrying him in his arms, and giving him boiled vegetables and the sick man was healed by his prayers. If his illness continued, Ahapit stayed with him incessantly, praying for him continuously, until the Lord gave health to the sick for his prayers. So, because of this, he was called a physician because the Lord had given him the gift of healing. And they heard about him in the city, that there was a doctor in the monastery, and many patients came to him and recovered” (Kolpakova, 2001).

Besides, in the $11^{\text {th }}$ century, there were secular doctors, who usually studied medicine in foreign countries or had a different religion, living in the Kyivan Rus. The Christian church did not influence such doctors. Among the secular doctors, some served princes, participated in military campaigns, and did not pay taxes for their medical activities. Secular doctors often visited the sick and got money for it. They examined patients, and then either prescribed specific drugs or predicted death. Their medical practice in most cases was not successful, because patients died without the necessary treatment and care. The researchers note, "The salary received by secular doctors was probably significant: in any case, in the chronicles, there were frequent complaints about the high cost of treatment and yet no effect from treatment” (Mirskii \& Bogôiavlenskii, 2018). During the time of Ahapit, a secular physician Armenian lived. He was also famous in the Kyivan Rus.

An Armenian once prophesied death to Prince Vsevolod: “An Armenian despaired him, predicting his death eight days later. The blessed Ahapit gave him the vegetables he ate and healed him. And the fame of him spread throughout the land" (Kolpakova, 2001). The Armenian became jealous of Ahapit and once sent to him "a man sentenced to death, ordering him to give Ahapit a poisonous drink so that he would fall dead before consuming it. The blessed Ahapit, seeing this, gave him monastic food and healed him with his prayers, and saved the prisoner from death” (Kolpakova, 2001).

Another prime example in favour of monastic medicine deals with the illness of Volodymyr Monomakh, Prince of Chernihiv. The Armenian again failed to cure the sick Prince and even exacerbated the disease. Ahapit helped again by sending the Prince healing vegetables, which he ate. Volodymyr Monomakh then recovered (Kolpakova, 2001).
Later, Ahapit became very ill, and "the Armenian visited him. He began to argue with Ahapit about the art of healing, talking about which drinks were used to treat different diseases. The blessed Ahapit answered, "To whom the Lord will give health". And the Armenian realized that he didn't know how to treat the sick. $<\ldots>$ And here they brought a patient from Kyiv. Ahapit got up, as if not sick, took the vegetables he ate, showed them to the doctor, saying, "This is medicine! Understand and see!" However, the doctor replied to the monk, "This is not our medicine, but I think it is brought from Alexandria”. The Blessed Ahapit laughed at his ignorance, gave the potion to the sick man, and healed him” (Kolpakova, 2001).

This medical discussion between Ahapit and the Armenian could be seen as a manifestation of a kind of competition between monastic and secular doctors. Since services of monastic doctors were free of charge, and secular ones, as mentioned, were feepaying (Mirskii \& Bogoiavlenskii, 2018).

Among other famous monks, there were also Damian (? - 1071) and Hryhorii (? - 1093), who "resorted to prayers, and for this, he defeated the demons" (Kolpakova, 2001), i.e., treated the mental disorders.

In "The Lives of the Saints” (1689) Dmytro of Rostov described Damian as follows, "with humility and obedience, considering himself unworthy of the gift of healing, Damian then performed painful prayers and anointed the sick with oil, and, by God's grace, all received healing and went healthy” (Zhitiya svyatykh na ..., 2004)

The icon painter Alimpii $(1065$ - 1114) could also treat the sick. The Kyivan Cave Patericon states that "one of the rich people of Kyiv suffered from leprosy and was treated by many magicians and doctors, he even sought help from people of other religions and did not recover, but only healed, and one of his friends forced him to go to the Pechersk monastery and ask some fathers to pray for him. He was brought to the monastery, the abbot ordered him to drink from the well of St. Feodosii, and his head and face were anointed with that water. $<\ldots>$ Alimpii, on the other hand, painted his face with artistic paint and smeared purulent scabs, and thus returned it to its first good appearance. He brought him to the Divine Church of Pechersk, allowed him to partake of the Holy Mysteries, and ordered him to wash with the water where the priests wash up. His scabs immediately disappeared, and he was healed of his illness" (Kolpakova, 2001).

In 1106, Mykola Sviatosha (1080 - 1143), Prince of Chernihiv, built a hospital monastery (Kiyevo-Pecherskaya..,1909). Besides, the Prince had a secular doctor Petro Siriianyn. However, Petro Siriianyn's methods of treatment were not successful. Once upon a time, the Prince was sick. Before the doctor's arrival, the Prince recovered, not allowing himself to be treated. And it happened more than once. One day Petro fell ill and Sviatosha sent to him such a message, "If you don't drink the potion, you'll recover soon. If you don't listen to me, you'll suffer a lot". As a result, Petro was healed by Sviatosha's prayers. When he fell ill again, Sviatosha sent to tell him, "You will recover in 3 days if you are not treated". Thus, Petro Siriianyn obeyed him and recovered in three days.... (Kolpakova, 2001).

Being in the monastery, Mykola Sviatosha predicted the death of his doctor. However, Petro Siriianyn understood that the Prince was prophesying his own death. He asked, "Please, could you describe to me, your servant, a deadly disease? And if I do not cure it, then my head will be for your head, and my soul will be for your soul!” (Kolpakova, 2001). Sviatosha replied, "I did not need treatment during my life, neither the dead can see life again nor doctors can resurrect” (Kolpakova, 2001).

In the Kyivan Cave Patericon, there is a brief mention of another healer Pymen (? - 1114), who has healed the sick and foreseen the future (Kolpakova, 2001). 
It is worth mentioning that the process of treatment by the first monks both in the Kyivan Cave Patericon" and "The Lives of the Saints" by St. Dmytro of Rostov is described as "a spiritual service. The ability to heal people was a gift of God, revealed to the righteous people for their spiritual feat, and healing was an integral part of serving the Lord” (Dzeman, 2018). The number of the first monk-doctors was small; otherwise, there would be more mentions in historical chronicles.

In the first monastic hospitals on the territory of modern Ukraine, monks had to follow certain rules, in particular, they had to do the hardest work while caring for the sick; be tolerant in their treatment; not to worry about personal enrichment, etc. The monks were not only doctors but also educators, because "they kept manuscripts, engaged in the translation of Greek and Latin books with medical content. At the same time, they enriched them with their knowledge" (Marchukova, 2003). However, M. Mirskyi and N. Bohoiavlenskyi argue in this regard and note that "the main occupation of the monks, although they were representatives of intellectual culture, was most likely not the study and copying of ancient literature (and especially not the healing of the sick), but theology which absorbed the main intellectual intentions of the clergy. The heroism of unknown monks who devoted themselves to charitable activities during the treatment of the sick and suffering deserved more respect” (Mirskii \& Bogoiavlenskii, 2018).

Besides, there were "Svyatoslav's Collection" (Izbornyk Svyatoslava) (1073) and "Svyatoslav's Collection" (1076), the fundamental encyclopedic works of the Kyivan Rus connected with various spheres of human life. These works were translations from Bulgarian. As for medicine, these "Collections" are the first textbooks, which described certain diseases, the algorithm of their treatment, recommendations for proper nutrition (vegetables, fruits, cereals, fish, etc.), ways to prevent diseases. Moreover, there was information about physicians and surgeons of that time.

Women of the Kyivan Rus were also interested in medicine. According to the canonical version, the first prominent womandoctor and the first medical scientist in the history of RusUkraine was Dobrodiia-Yevpraksiia-Zoia (1108 - 1172), the daughter of the Grand Duke of Kyiv Mstyslav and granddaughter of Volodymyr Monomakh, great-granddaughter of Yaroslav the Wise. In her youth, Princess Yevpraksiia got involved with folk medicine. She collected medicinal herbs, prepared infusions, and treated both the nobility and the common people. For this, she was sometimes considered to be a witch. After marriage and moving to Byzantium, in the 30s of the $12^{\text {th }}$ century Yevpraksiia wrote a scientific work "Alima" (Ointments) in Greek. The treatise included 5 parts and 29 chapters. The work became quite popular in the Middle Ages because it combined Yevpraksiia's medical practice and analysis of other physicians' activity (Kitsera, \& Kitsera, 2010).

However, as O. Tkachivska notes, "today there are not enough facts to claim that the author of the first domestic medical work "Alima” (Ointments), written in Greek, was the Kyivan princess Zoia Mstyslavivna” (Tkachivska, 2009). The discussion of the early $20^{\text {th }}$ century, initiated by H. Loparev (1902) and S. Papadimitriou (1904), was continued in the 1970s by G. Litavrin, who investigated fragments of treatise photocopies. He stated that "we have a collection of medical tips, which are of a practical purpose - to be a guide for doctors, a kind of medical encyclopedia, a part is, perhaps, a compilation, another part is original (let the experts decide). It was made by a practitioner who did not refrain from his remarks, offering his methods of treatment...” (Litavrin, 1971). This fragment of the translation deals with the basics of healthy eating; internal organs, infectious diseases, chronic diseases, and their treatment; elements of anatomy; pregnancy, a post-natal period for women and newborns, etc. (Litavrin, 1971).

O. Viesielkova notes that "until the $17^{\text {th }}$ century, medical service developed spontaneously, without state influence; there even was no state system of training doctors” (Veselkova, 2018).
L. Zmieiev pointed out that "monasteries did not teach medicine as a speciality and therefore could not influence the formation of medical staff" (Zmeev, 1896).M. Dzeman also adds that "in the $10^{\text {th }}-12^{\text {th }}$ centuries the foundation of centres for mass medical care and schools for the broad training of doctors, according to modern ideas, was simply impossible for technical reasons" (Dzeman, 2018).

However, "The Church Statute of Prince Volodymyr" $\left(10^{\text {th }}\right.$ century), which was one of the first official documents regulating specific state issues, referred to lichtsi (doctors) who belonged to the ecclesiastical people (Cherepnin, 1976). Thus, this statute applied only to monastic medicine. Doctors approved by the church were to ensure that newborns were baptized and those who died were confessed and buried according to Christian ritual (Zmeev, 1896). "The True Russian” $\left(11^{\text {th }}\right.$ century), another state document, also mentioned secular medicine. In particular, paragraph 30 states that "If someone damages a person with a sword but does not kill, he will pay 3 hryvnias, and a hryvnia will go to the victim for a wound for treatment..." (Grekov, 1940).

Despite the development of monastic and secular medicine in the Kyivan Rus, folk medicine continued to exist, guided by moral and ethical principles.

Speaking of the first school in the Kyivan Rus, I. Ohiienko mentions the name of its founder, Princess Anna Vsevolodivna (second half of the $11^{\text {th }}$ century $-1112(3)$ ), and points out that "in 1086 Anna or Yanka laid in her monastery the first girls' school, accepted all girls who wanted to study. However, there was no information in the chronicles about Anna's school, only about the monastery, which was often identified with the school of that time" (Ohiienko, 2003). Apparently, in this school, the girls were taught not only the fine arts of the time but also household items, among which there were the basics of medicine. Therefore, there are reasons to consider this establishment a prototype of medical educational ones.

In the $13^{\text {th }}$ century, the development of medicine, and hence the transfer of medical knowledge, was reduced because of the Tatar and Mongol invasion in 1238 - 1240. It, on the contrary, slowed down the life of the Kyivan Rus, dividing it territorially.

\section{Conclusions}

Thus, many peoples lived on the territory of modern Ukraine at different times. They left a noticeable mark in the development of medicine and, accordingly, medical education. The study has found out that the origins of Ukrainian medical education are the period of Proto-Slavic medicine $\left(6^{\text {th }}\right.$ century BC $-7^{\text {th }}$ century $\mathrm{AD}$ ) and the period of folk, secular and monastic medicine of the Kyivan Rus $\left(9^{\text {th }}-13^{\text {th }}\right.$ centuries AD).

The period of Proto-Slavic medicine is the beginning of the activity of healers, fortune- tellers, priests, magicians, midwives, who could combine the rational things with the irrational ones, i.e. they used animate and inanimate nature and the power of words. There were two categories of so-called "specialists" which correspond to contemporary "general practitioners" and “surgeons”. Medical knowledge and experience were transmitted from generation to generation, sometimes people paid for it. Besides, the first medical circles were established during the Scythian time on the territory of modern Ukraine.

In the period of folk, secular, and monastic medicine of the Kyivan Rus there was a combination of pagan and Byzantine ideas in all spheres of life. Firstly, there were monasteries, mostly with hospitals and monks-doctors who used prayers and special methods of treatment. Secondly, wealthy people had doctors who either studied medicine in other countries (Egypt, Greece, Byzantium) or were of foreign origin. Thirdly, folk (pagan) medicine continued to develop. It should be noted that there was a kind of competition between these three areas. As for medical education, the representatives of folk medicine continued to pass on knowledge from generation to generation, 
sometimes for a fee; the monks combined the principles of folk medicine with the achievements of foreign colleagues, teaching those who decided to join them. Also, both monks and secular physicians attempted to translate and create their treatises, which were the first textbooks in medicine and pharmacology. Although the mass establishment of medical schools during the Kyivan Rus did not take place, however, we should talk about the school of Princess Anna Vsevolodivna, as one of the earliest establishments of medical education in Ukraine.

\section{Literature:}

1. Education | Definition, Development, History, Types, \& Facts [Internet]. Encyclopedia Britannica. 2020 [cited 3 Dec 2020]. Available from: https://www.britannica.com/topic/education. 2. Mirskii, M., \& Bogoiavlenskii, N.: Meditsina Drevnei Rusi [Medicine of Ancient Rus]. Moscow: Rodina, 2018. 416 p. ISBN 978-5-907024-14-4.

3. Palamarchuk, Ye, \& Andriievskyi, I.: Zori Trypillia [Trypillia Stars]. $2^{\text {nd }}$ ed. Vinnytsia: Teza, 2005. 132 p. ISBN 966-8317-54-8. 4. Blikhar, Ye.: Pro medytsynu skifiv [About the medicine of the Scythians]. Vol. 1. Collection of works Ternopil branch of the Scientific Shevchenko Society, 2004. p.172-176.

5. The History, vol. 2 | Online Library of Liberty [Internet]. Oll.libertyfund.org. 2020 [cited 10 Dec 2020]. Available from: https://oll.libertyfund.org/title/the-history-vol-2\#lf1300-02_labe $1 \_240$

6. Hippocrates: O vozdukhe, vodakh i mestnostyakh [Air, Waters and Places]. [In Russian]. Trans Latyshev VV. Vol. 2. Bulletin of Ancient History, 1947. p. 294-298.

7. Skolozdra, S.V., \& Tchaikovskyi, B.P.: Natsionalna ideia yak skladova Bolonskoho protsesu [National idea as a component of the Bologna process]. Vol. 13(3). Scientific Bulletin of Stepan Gzhytskyi National University of Veterinary Medicine and Biotechnologies Lviv, 2011. p. 270-277.

8. Kostomarov, M.I.: Slovyanska mifolohiia [Slavic mythology]. Kyiv: Lybid, 1994. 384 p. ISBN 5-325-00183-3.

9. Zmeev, L.F.: Chteniya po vrachebnoy istorii Rossii [Readings on the medical history of Russia]. St. Petersburg: Printing house of Demakov V.F., 1896. 264 p. ISBN 9785998994579.

10. Veselkova, E.G.: Meditsinskoye obrazovaniye $v$ Rossii: istoriya, sovremennoye sostoyaniye, printsipy [Medical education in Russia: history, current state, principles]. [Internet]. Vol. 3. Pedagogy of professional medical education, 2018. ISSN 2686-7176. [cited 23 Dec 2020]. Available from: https://www.profmedobr.ru/wp-content/uploads/2018/12/032018-\%D0\%92\%D0\%B5\%D1\%81\%D0\%B5\%D0\%BB\%D0\% BA\%D0\%BE\%D0\%B2\%D0\%B0-06-14_.pdf.

11. Ivashchenko, I.Y.: Ukrayinska narodna medytsyna [Ukrainian folk medicine]. Vol. 1. Nursing, 2012. P. 23-28. 12. Zhylenko, I.: Slovo do chytacha. Dzherela ta istoriia tekstu Pecherskoho pateryka [A word to the reader. Sources and history of the text of the Pechersk Patericon]. In Kolpakova, V.M., ed.: Pateryk Kyyevo-Pecherskyy [The Kyivan Cave Patericon] [Internet]. $2^{\text {nd }}$ ed. Kyiv: Publishing House "KM Academy”, 2001. 348 p. [cited 20 Dec 2020]. Available from: http://izbornyk.org.ua/paterikon/paterikon.htm.

13. Kiyevo-Pecherskaya Lavra [The Kyiv Pechersk Lavra]. Kyiv: Printing House of the Kyiv Pechersk Lavra, 1909. 31 p.

14. Kolpakova, V.M., ed.: Pateryk Kyyevo-Pecherskyy [The Kyivan Cave Patericon] [Internet]. $2^{\text {nd }}$ ed. Kyiv: Publishing House "KM Academy", 2001. 348 p. [cited 20 Dec 2020]. Available from: http://izbornyk.org.ua/paterikon/paterikon.htm 15. Marchukova, S.M.: Meditsina v zerkale istorii [Medicine in the mirror of history]. Moscow: European House, 2003. 272 p. ISBN 5-8015-0151-7.

16. Dzeman, M.I.: Do 100-richchya zasnuvannia Natsionalnoyi akademiyi nauk Ukrayiny: aktsentovani pytannia $v$ dyskursi evolyutsiyi medychnykh piznan ukrayintsiv (2-he podannya) [To the $100^{\text {th }}$ anniversary of the National Academy of Sciences of Ukraine foundation: highlighted issues within the discourse of the medical knowledge evolution of Ukrainians $\left(2^{\text {nd }}\right.$ submission)]. Vol. 7 (4). Practical doctor, 2018. p. 53-70. ISSN 2413-5461.

17. Zhitiya svyatykh na russkom yazyke, izlozhennyye po rukovodstvu Chetikh-Miney sv. Dimitriya Rostovskogo [The
Lives of the Saints in Russian, set out according to the leadership of the Chetikh-Minea by St. Dimitri Rostovsky]. Vol. II. October. Kiev: Holy Dormition Kiev-Pechersk Lavra, 2004. p. 260-311.

18. Kitsera, N.I., \& Kitsera O.O.: Dobrodiia-Yevpraksiia Mstyslavivna - persha zhinka-likar $v$ istoriyi Rusi-Ukrayiny [Dobrodiia-Yevpraksiia Mstyslavivna - the first woman-doctor in the history of Rus-Ukraine]. Vol. 1. Female doctor: a scientific-practical view for practitioners, 2010. p. 49-50.

19. Tkachivska, O.: Yevpraksiia-Zoia $i$ medychnyy traktat "Mazi" [Evpraksiia-Zoia and medical treatise "Ointments"]. Vol. XXIV: Medical collection. Medicine and biology. Proceedings of the Scientific Society named after Shevchenko, 2009. p. 51-56.

20. Litavrin, G.G.: Vizantiyskiy meditsinskiy traktat XI-XIV vv. [Byzantine medical treatise of the $11^{\text {th }}-14^{\text {th }}$ centuries]. Vol. 31 (56). Byzantine Calendar, 1971. p. 249-301.

21. Cherepnin, L.V., ed.: Ustav knyazya Vladimira o desyatinakh. Drevnerusskiye knyazheskiye ustavy XI-XV vv. [Church Statute of Prince Vladimir. Ancient Russian princes of the $11^{\text {th }}-15^{\text {th }}$ centuries]. Moscow: Nauka, 1976. $240 \mathrm{p}$.

22. Grekov, B.D., ed.: Pravda Russkaya [True Russian]. Vol. 1. M.; L.: Publishing house of the Academy of Sciences of the USSR; 1940. 505 p.

23. Ohiienko, I.: Kniahynia Yanka - zasnovnytsia pershoyi zhinochoyi shkoly khudozhnikh remesel u Kyyevi [Princess Yanka - the founder of the first girls' school of arts and crafts in Kyiv]. Vol. 1-2. People, creativity, and ethnography, 2003. p. 6370. ISSN 01306936.

\section{Primary Paper Section: A}

Secondary Paper Section: AB, AM 